\title{
T. Гуменюк,
}

доктор історичних наук, доцент, професор кафедри права

ПВНЗ «Університет Короля Данила»

\section{ВІДПОВІДАЛЬНІСТЬ ДЕРЖАВНИХ СЛУЖБОВЦІВ ЗА КОРУПЦІЙНІ ПРОЯВИ (НА ПРИКЛАДІ ОКРЕМИХ КРАЇН ЄВРОПИ)}

У сучасних демократичних суспільствах уже започаткована й ефективно функціонує система заходів боротьби з корупцією в секторі безпеки, яка побудована на невідворотності відповідальності за вчинення будь-яких корупційних злочинів, незважаючи на час і персоналії. На особливу увагу заслуговує досвід закордонних країн, які реалізували антикорупційні програми, досягли необхідних позитивних результатів і заклали підвалини сталого суспільно-політичного розвитку, зокрема в контексті гарантування національної безпеки. Усі держави - члени Ради Європи ухвалили кримінальне законодавство, а іноді й супутні підзаконні акти, щодо корупції взагалі, особливо стосовно державних службовців. Наприклад, отримання державним службовцем неправомірної вигоди суворо карається в усіх державах-членах. Проте $€$ різні визначення поняття корупціі. У законодавстві держав-членів не існує єдиного розуміння, окрім того факту, що надання й отримання неправомірної вигоди є явищем корупційної поведінки та карається відповідно до кримінального законодавства.

Актуальні питання відповідальності державних службовців за корупційні прояви в європейських країнах розглядали О. Задорожній,
А. Тіньков, Ю. Дем'янчук, О. Новікова, О. Губанов, Н. Підбережник, К. Буряк, Н. Янюк, О. Васильєва, Н. Ахтирська, Т. Ільєнок, Т. Супрун, Т. Хабарова, Д. Ковриженко й інші науковці.

3 урахуванням наявної проблеми, а також ступеня іiі дослідження, метою даної статті виступають загальні особливості системи боротьби з корупцією та методи усунення цього негативного явища у країнах Європи.

$\mathrm{У}$ європейському контексті одним із перших джерел «м'яких» (юридично необов'язкові) міжнародних стандартів, які вказують на необхідність створення спеціалізованих інституцій або призначення посадових осіб, відповідальних за запобігання злочинам, пов'язаним із корупцією, розслідування таких і кримінальне судове переслідування порушників, стали «Двадцять керівних принципів боротьби проти корупції, ухвалені Радою Європи в 1997 р. У 1998 р. більшість цих принципів відображені у Кримінальній конвенції Ради про боротьбу проти корупції. Спочатку міжнародні юридичні інструменти концентрувалися на запровадженні спеціалізації правоохоронних органів і органів прокуратури, що мало сприяти ефективнішому дотриманню антикорупційного законодавства [1, с. 13]. 
У Конвенції Організації Об’єднаних Націй (далі - ООН) проти корупції (31 жовтня 2003 р.) наголошено важливість закріплення у внутрішньому законодавстві норм із запобігання конфлікту інтересів. У ч. 5 ст. 8 Конвенції наголошено на запровадженні заходів і систем, які «зобов'язують державних посадових осіб надавати відповідним органам декларації, inter alia про позаслужбову діяльність, заняття, інвестиції, активи та про суттєві дарунки або прибутки, у зв'язку 3 якими може виникнути конфлікт інтересів стосовно їхніх функцій як державних посадових осіб». У Міжнародному кодексі поведінки державних посадових осіб як Додатку Резолюції 51/59 Боротьби з корупцією (від 12 грудня 1996 р.) також першочергово виділено питання запобігання конфлікту інтересів. Згідно зі ст. 5 Міжнародного кодексу, державні посадові особи «повинні повідомляти про ділові, комерційні або фінансові інтереси чи діяльність, що реалізується для отримання фінансового прибутку, які можуть призвести до ймовірного конфлікту інтересів». 3 огляду на гостроту питання, Комітет міністрів Ради Європи ухвалив Рекомендації № R (2000) 10 (від 11 травня 2000 р.) «Про кодекси поведінки державних службовців». У Додатку до Рекомендації № R (2000) 10, Модельному кодексі поведінки для публічних службовців наголошено на необхідності своєчасного врегулювання конфлікту інтересів публічного службовця, який може перешкоджати належному виконанню службових обов'язків [2].

Чинним законодавством держав членів Європейського Союзу закріплено широкий перелік правових засобів, здатних ефективно протидіяти різноманітним формам прояву корупції. Натепер корупційним злочинам відведено важливе місце у кримінальному законодавстві європейських країн. Окреслимо специфіку правової регламентації кримінальної відпові- дальності за вчинення корупційних діянь. По-перше, незважаючи на відсутність кодифікованих джерел у країнах загального права, корупційні злочини у структурі кримінального законодавства (наприклад, у Великобританії й Ірландіi) зазвичай виділені в самостійну категорію на основі критеріїв суб'єкта й об'єкта посягання. По-друге, кримінальні кодекси більшості держав - членів Європейського Союзу містять норми, що встановлюють відповідні правові заборони. По-третє, у кримінальних законах держав - членів Європейського Союзу основною кваліфікуючою ознакою нерідко виступає не об'єкт посягання, а суб'єкт корупційного правопорушення - посадовець. Відповідно до § 304 Кримінального кодексу (далі - КK) Австрії, суб'єктом «прийняття подарунка» може виступати посадовець або третейський суддя. Згідно з $\$ 74$ KK Австрії, посадовцем $€$ кожен, хто обіймає посаду в законодавчому органі, в органах правосуддя і в адміністрації, зокрема на державних підприємствах (виняток становлять члени Національної ради, бундесрату й ландтагу) [3].

Країни Європейського Союзі (далі - ЄС) дуже різняться як за станом корупціï, так і за методами боротьби з нею. Останніми роками щорічний рейтинг як одна 3 найменш корумпованих країн очолює Данія. Їй притаманна інформаційна прозорість діяльності державних структур і свобода доступу преси до документів, на яких ці рішення грунтуються. Тут немає спеціалізованого органу, який очолює діяльність щодо протидії корупції, лише запроваджено ключові державні та приватні антикорупційні ініціативи, пов'язані з веденням бізнесу, який контролюють громадські організації. Антикорупційну діяльність у Данії спрямовано на превентивні заходи. Зокрема, Данське агентство міжнародного розвитку Danida, що реалізує програми розвитку та передбачає надання безвідсоткових позик 
для фінансування проєктів, розвиває політику абсолютної нетерпимості в межах компанії та під час співпраці із зовнішніми партнерами. Усі контракти Danida містять антикорупційні положення, що стосуються всіх умов контракту, тобто компанії повинні укладати декларацію про заборону хабарництва як прояву корупції. Порушення відповідного положення призводить до розірвання контракту й відмови від подальшого партнерства [4, с. 348]

Загалом світовий досвід у сфері врегулювання конфлікту інтересів $€$ цікавим та неоднорідним. Так, одним із перших у світі актів, яким регулювалося дане питання, був Закон про попередження корупції 1889 р., ухвалений у Великій Британіі. Британський підхід був заснований на ідеї, що конфлікти інтересів $€$ передусім «аспектом етичних стандартів у державному секторі». Спеціально створений Комітет зі стандартів суспільного життя давав рекомендації державним службовцям стосовно вирішення конфліктів інтересів. Надалі практика створення таких органів із широкими повноваженнями у сфері боротьби 3 корупцією стала дуже поширеною. $\mathrm{У}$ цьому аспекті показовим $є$ досвід Латвії, де положення про конфлікт інтересів є частиною широкої політики запобігання корупції та боротьби з нею, а авторитетне, наділене широкими повноваженнями, незалежне Бюро із відвернення та боротьби з корупцією відповідає за виявлення, розслідування та притягнення до відповідальності в корупційних справах. Поширена практика фінансового контролю державних службовців. Так, у Португаліі, серед іншого, існує практика декларування держслужбовцями доходів та майна (майновий стан), вільного доступу до цих даних громадськості. Така ж практика існує в Іспанії, яка доклала значних зусиль для ефективного вирішення проблем урегулювання конфліктів інтересів зокрема та корупції загалом. Так, державні службовці зобов'язані повідомляти про виникнення конфлікту інтересів, а також проходити фінансовий контроль шляхом декларування власного фінансового та майнового стану у процесі обрання на посаду, щорічно під час здійснення повноважень, а також на момент звільнення 3 посади. Також держслужбовці зобов'язані повідомляти про ймовірну приватну діяльність після звільнення з держслужби. Також іспанське законодавство зобов'язує подавали декларації про попередні місця роботи, зокрема й роботу консультантом, або про іншу зайнятість. У свою чергу, цікавим $€$ французький підхід, відмітною рисою якого $є$ стурбованість стосовно діяльності держслужбовців після їх звільнення зі служби, а саме встановлення кримінальної відповідальності за конфлікт інтересів під час проходження державної служби та діяльність після звільнення в компаніях, що були йому підконтрольні як державному службовцю протягом останніх п'яти років [5, с. 100-101]. Запобіганню корупції в державному апараті Франції сприяють специфічні обмеження, які застосовуються щодо державних службовців. Їхня діяльність регулюється Конституцією Франції 1958 р. та Загальним статутом державних службовців, який включає чотири основні закони, зокрема: «Про права та обов'язки державних службовців» від 13 липня 1983 р.; «Про центральну державну службу» від 11 січня 1984 р.; «Про територіальну державну службу» від 26 січня 1984 р.; «Про державних службовців системи охорони здоров'я» від 9 січня 1986 р. [6, с. 124]. Основними державними інституціями Франції, які здійснюють боротьбу з корупцією, є: Комісія з фінансової гласності політичного життя, що контролює майнове становище парламентаріїв, Національна комісія з рахунків виборчих кампаній і фінансування політичних партій, правоохоронні органи, Міністерство юстиціі; Відділ з боротьби 
проти корупції (далі - ВБК), що діє із 2004 р. в рамках Управління боротьби проти економічних та фінансових злочинів при Судовій поліції; Центральна служба запобігання корупціі. Зокрема, Центральну службу запобігання корупції було створено в 1993 р. На неї покладено такі важливі функції, як: розроблення та впровадження системи антикорупційних заходів, розгляд випадків фінансових зловживань на службі з боку як державних службовців, так i приватних осіб, хабарництва, дій із корисливою метою, надання незаконних пільг чи переваг під час проведення тендерних торгів; надання рекомендацій щодо організації протидії корупції. Головою служби є суддя, якого призначає президент Франціiі. До іiі складу входять представники різних міністерств та відомств. У разі надходження інформації, що свідчить про факти правопорушень, Центральна служба направляє матеріали Прокурору Республіки для проведення розслідування. Також Центральна служба запобігання корупції здійснює інформаційно-просвітницьку діяльність та сприяє ухваленню етичних кодексів в організаціях як державного, так і приватного секторів. Важливу роль у протидії корупції, насамперед у боротьбі 3 марнотратством та казнокрадством, у Франції відіграють Держрада, Рахункова палата і Генеральна інспекція фінансів. Держрада консультує уряд на предмет відповідності законодавству Франції всіх підзаконних актів міністерств і відомств (накази, інструкції, регламенти тощо), а також $є$ вищою інстанцією системи адміністративної юстиції, що розглядає спори між громадянами і чиновниками [6, с. 125].

Щодо протидії корупції серед державних службовців у Німеччині, то, відповідно до споконвічної німецької доктрини, чиновника в цій країні розглядають як слугу, орган і представника держави, державної ідеї. Правовий статус федеральних чиновників
Німеччини регулюється двома найважливішими законами: «Про державних службовців» від 27 лютого 1985 p. і «Про правове положення чиновників» від 27 лютого 1985 р. У розд. 29 КК Німеччини «Посадові злочинні діяння» у низці норм передбачено кримінальну відповідальність особи, яка «спеціально уповноважена на виконання публічних обов'язків», тобто працівника, який, не будучи власне посадовцем, реалізує функції публічного управління при органі влади або зайнятий в установі чи об'єднанні, що здійснює такі функціi. Варто зазначити, що хабарництво (bribery) як форма прояву корупціi $€$ актом пропозиції посадовцю грошей, послуг або інших цінностей із метою переконати його зробити щось у відповідь. У всіх кримінальних кодексах держав - членів ЄC існують склади активного і пасивного хабарництва. Із січня 2006 р. у Німеччині набрав чинності Закон «Про доступ до публічної інформації» у новій редакції. Він гарантує не лише журналістам, але й простим громадянам право доступу до будь-якої чиновницької інформації, за винятком тієї, що має гриф «таємно». Громадяни навіть не зобов'язані пояснювати причину свого інтересу. Закон не передбачає прямого покарання чиновників за ненадання інформації. Але на підставі цього Закону громадянин може звернутися до суду або до уповноваженого 3 інформаційної свободи і таки домогтися отримання необхідної йому інформації. На практиці в Німеччині не задовольняється приблизно третина всіх запитів. Здебільшого через гриф «таємно», зазвичай це інформація зі сфери оборони та спецслужб. Водночас деякі установи намагаються, так би мовити, «креативно» обійти право громадян на інформацію. Найчастіше вони просто прикриваються формулюванням «справи державні» [6, с. 125].

Важливим чинником, який сприяє проведенню успішної політики протидії корупції у Франції, є активна участь 
цієї країни в антикорупційній діяльності Європейського Союзу. Францією ратифіковано всі антикорупційні конвенції Євросоюзу. Їі правоохоронні органи активно співпрацюють із Європейським поліцейським управлінням (Європол), Європейським бюро судової співпраці (Євроюст), ОЛАФ (спеціальний підрозділ фінансової поліції при Європейському Союзі, до функцій якого належить боротьба із шахрайством). Окрім цього, подоланню проявів корупції в державному секторі Франції сприяють такі об’єктивні чинники, як збільшення ролі мережевого управління порівняно із традиційною ієрархічною вертикаллю влади, зменшення втручання держави в економічні процеси та регламентації сфери послуг [6, с. 126].

У Центральній та Східній Європі значна увага приділяється ухваленню детальних антикорупційних законів, які спрямовані на визнання кримінальними всього спектра діянь, пов'язаних із хабарництвом; більшість країн також запровадили програми боротьби з корупцією на національному рівні. Відповіддю на боротьбу 3 корупцією в багатьох країнах ЄC стало зростання кількості підзаконних актів, які мають антикорупційних характер. Щодо оплати чиновників між Україною, Угорщиною, Словаччиною, Чехією й іншими країнами «Вишеграду», Європейського Союзу існує колосальна різниця. Зокрема, у результаті адміністративної реформи й адміністративно-територіальної та взагалі реформи державної служби ці країни взяли курс на виховання цілого класу людей - як політиків, так і просто службовців без політичного статусу, які мають гідну плату за свою роботу, і тому боротьба з корупцією в цих країнах матиме свої результати якщо не зараз, то в довгостроковій перспективі, тому що люди цінуватимуть цю роботу, будуть цінувати право представляти людей i працювати на людей. Боротьба з корупцією як один із головних прі- оритетів уряду Чеської Республіки (далі - ЧР) грунтується на стратегії уряду в боротьбі з корупцією протягом 2013 і 2014 рр., яка затверджена постановою Уряду від 16 січня 2013 р. № 39 [7, с. 19]. Стратегія розділена на дві частини, а саме аналітичну та стратегічну. Аналітична частина складається із трьох розділів: сприйняття корупції, якісний аналіз економічних аспектів корупції, виявлення i розслідування корупції. Стратегічний розділ містить основні стратегічні напрями. До них належать: професіоналізація державного управління, управління державним майном, зміцнення інструментів боротьби з корупцією у приватному секторі, зміцнення політичної системи та підвищення прозорості політичних партій, виявлення, розслідування і кримінального переслідування корупційних правопорушень, зміцнення антикорупційного клімату в чеському суспільстві, створення моніторингу корупції, боротьби з корупцією та координації дій антикорупційної політики, зміцнення ресурсів для реалізації антикорупційної політики, підвищення прозорості в державному секторі [7, с. 20].

Як свідчить міжнародний досвід, боротьба 3 корупцією досягає успіху лише за умови іï комплексного характеру, коли вона охоплює якнайбільше сфер життєдіяльності держави, ведеться постійно та перебуває в центрі уваги як влади, так і громадськості. Така діяльність у більшості європейських країн, зокрема і у Словаччині, проводиться системно і базується на основних принципах верховенства права, законності, системності, практичної спрямованості та радикальних заходів взаємодії владних структур з інститутами суспільства і населенням тощо. Особливістю антикорупційної політики у Словацькій Республіці є те, що тут було ліквідовано Центральне координаційне управління боротьби з корупцією та Комітет боротьби 3 корупцією i створено відділ боротьби з корупцією Секретаріату Уряду Словаччини, 
основним завданням якого $€$ координація дій міністерств та відомств у сфері боротьби з корупцією. Безпосередньо реалізацією заходів у межах Національної програми боротьби 3 корупцією займаються Управління боротьби 3 корупцією Президіі поліцейського корпусу Міністерства внутрішніх справ Словаччини та Словацька інформаційна служба. Крім цього, основні повноваження боротьби 3 корупцією перейшли від Міністерства фінансів до Міністерства юстиціі Словаччини. У структурі Міністерства внутрішніх справ Словацької Республіки діє Антикорупційний комітет, до повноважень якого входить ужиття превентивних заходів та розслідування фактів корупції серед співробітників міністерства та поліцейських структур країни [7, с. 21]. Щодо оцінки державної політики боротьби з корупцією, то, за даними Transparency International, Словаччина у 2012 р. була на 62 місці (зі 176) щодо запобігання та протидії корупціі. Крім того, істотною проблемою у сфері антикорупційної політики $є$ ситуації щодо судочинства у Словаччині. Слабкість та залежність судової гілки державної влади визначається істотним впливом та втручанням із боку політиків, а також значним обсягом справ у судах, що зумовлено переходом до демократичного режиму державної влади. Це зумовлює затягування розгляду справ, а також постійні зміни законодавства. Щодо деяких позитивних зрушень фахівці Transparency International зазначають: прозорість та підзвітність судочинства покращилась після обов'язкової публікації рішень судів у реєстрі судових рішень у мережі Інтернеті із 2012 р.; укладення публічних договорів (контракти) стало більш прозорим через обов'язкове розміщення їх в Інтернеті, як і публікація всіх рахунків за ними [7, с. 23-24].

Прибалтійські держави (Литва, Латвія й Естонія) - єдиний приклад колишніх держав Радянського Союзу, що набули повноправного членства в Європейському Союзі. Зважаючи на спільне минуле, історичні передумови, а також значний прогрес в антикорупційній політиці цих держав, їхній досвід важливий для вивчення та формування пропозицій з удосконалення управлінських механізмів запобігання та протидії корупції в Україні. За результатами досліджень, що проведені міжнародною організацією Transparency International, y 2012 р. у світовому рейтингу корупції Литва за індексом сприйняття корупції посіла 48 місце серед 176 країн світу (у 2011 р. - 50 місце серед 183 країн), набрала 54 бали зі 100. Після відновлення незалежності в 1990 р. та до вступу в Європейський Союз і НАТО у 2004 р. Литві вдалося створити у країні систему боротьби 3 корупцією, яка є однією 3 найкращих у Європі. В основі іiі діяльності лежить комплексний підхід, що поєднує превентивну і репресивну функціï, правові й організаційні механізми [7, с. 32]. У 2002 р. ухвалений Кримінальний кодекс Естоніі. Ним було встановлено серйозну відповідальність за корупцію. Одержання хабаря загрожує в'язницею - до п'яти років (повторне - до десяти років), посередництво в хабарі - великим штрафом або позбавленням волі. У разі підношення цінного подарунка, хабаря суд, окрім позбавлення волі, може застосувати конфіскацію майна. Факти корупції розслідують три органи: Префектура поліціі - якщо йдеться про чиновника, що працює в органах самоврядування, а також у приватних підприємствах / об'єднаннях; Поліція безпеки - якщо йдеться про найвищих державних посадовців (президент, міністри); Державна прокуратура - якщо йдеться про правоохоронців. Питання боротьби 3 корупцією в Естонській Республіці належить також до компетенції Центру дослідження корупції при Інституті Яана Тиніссона та Центру етики Тартуського університету. В Естонії впроваджена координована співпраця 
різних відомств під контролем Кримінально-превентивної ради, до складу якої входить приблизно 30 представників правоохоронних органів, суду, адвокатури, соціального забезпечення й інших державних органів, а також громадськості. Рада координує кримінально-превентивну діяльність у державі, розробляє пропозиції для уряду країни, консультує в питаннях, що стосуються забезпечення правопорядку й антикорупційної політики. Змістом роботи Кримінально-превентивної ради є комплексна боротьба проти корупції й організованої злочинності, а головною метою іiі діяльності - запобігання злочинам через соціальні програми [7, с. 40].

Румунія характеризується найагресивнішою антикорупційною політикою в Європейському Союзі. У 2002 р. було створено Національний антикорупційний директорат Румунії за моделлю Італіі, покликаний викривати й розслідувати корупційні правопорушення. Намагання уникнути відповідальності окремими особами зумовило потребу передбачити у Кримінальному процесуальному кодексі Румуніі взаємне інформування правоохоронних органів різних країн про перетин кордону підозрюваними. $\mathrm{У}$ рамках міжнародного співробітництва діють спільні слідчі групи, що дає змогу ефективно виявляти осіб, які перебувають у міжнародному розшуку. Ускладненим є отримання інформації від провайдерів, а також одержання дозволу на проведення обшуку політиків тоді, коли ці особи лише пов'язані з корупційними оборудками. Членство Румунії в Євросоюзі дає змогу оперативно співпрацювати, зокрема перевіряти законність виявлених під час проходження митного контролю коштів в аеропорту протягом 8 годин, незалежно від місця затримання особи. Національний антикорупційний директорат Румунії є правоохоронним органом. Його функції полягають у кримінальному переслідуванні осіб, які вчинили корупційне правопорушення [8, с. 4]. Чинне законодавство Румунії передбачає можливість перевірки спадку, залишеного особою, яка підозрювалась у вчиненні корупційних правопорушень, однак не може бути притягнута до відповідальності через іiі смерть. Незважаючи на те, що спадкоємці нібито є законними набувачами активів, вони не можуть перешкоджати проведенню розслідування та перевірці джерел походження статків. У разі доведення шахрайського, корупційного походження майна та коштів воно підлягає конфіскації за загальним правилом. Беззастережною умовою фінансової прозорості посадовців у Румунії визнано постійний контроль за їніми статками. Десять осіб служби з повернення активів мають прямий доступ до більшості баз даних (нерухомості, демографічна, паспортна, транспортна, власників зброї, інтелектуальної власності). Кадрова політика є запорукою результативності діяльності уповноважених органів, зокрема, голова Національного антикорупційного директорату призначається не президентом країни, а Радою магістратури Румунії, до складу якої входить чимало представників громадськості. Прокурори НАДР є незалежними від Генеральної прокуратури, що гарантує проведення ефективного розслідування корупційних правопорушень у цьому відомстві [8, c. 5].

На європейському рівні має бути створено чіткі правила про період охолодження для представників влади, політиків і вищих державних службовців, які бажають піти зі своєї посади у приватний сектор. Ці мінімальні стандарти в державах-членах повинні підкріплюватися законом про державну службу або кримінальним правом, а Комісія повинна нести відповідальність за контроль їх дотримання. Доцільним є трирічний період охолодження, запропонований Transparency International. Також було б корисно ухвалити ці правила для 
таких країн, як Україна, де триває процес зближення 3 Європейським Союзом. Наприклад, державний сектор у Німеччині та Франції протягом багатьох десятиліть був відносно несприйнятливий до корупції. Як у Німеччині, так і у Франції закон про державну службу складено таким чином, що побутової корупції з боку державних службовців майже не існує, оскільки вона не виправдовує ризику довічної втрати роботи та дуже хорошої пенсії. Проте також можливі позитивні стимулюючі чинники. Нідерланди активно сприяли створенню культури професійної етики у своїй державній службі. Міністерством внутрішніх справ Нідерландів було створено національне управління з питань професійної етики [9].

Ефективна боротьба 3 корупцією $є$ важливою основою реалістичної перспективи членства в ЄС для цілісної та суверенної України. Громадянське суспільство України вже бере досить активну участь у процесі реформ i перетворень, які проходять у надзвичайно важких умовах. У багатьох важливих зацікавлених сторін громадянського суспільства існує величезне бажання викорінити корупцію, яка згубно позначається на повсякденному житті населення України. 3 корупцією можна ефективно впоратися шляхом забезпечення: 1) такої організації держави, яка забезпечувала б систему стримувань і противаг шляхом поділу та блокування повноважень; 2) професійної етики в державному секторі; 3) незалежності судової влади; 4) свободи та плюралізму преси як четвертої влади; 5) деконцентрації економічної влади та іiі впливу на політику; 6) активного громадянського суспільства, розвиток якого, проте, значною мірою залежить від попередніх аспектів. У державній службі, тобто державній адміністрації в рамках виконавчої влади, необхідно ухвалити правові норми, які будуть перешкоджати зловживанню владою з боку посадових осіб. До них нале- жать ефективні санкціі, а саме заходи із закону про цивільну службу, дисциплінарного та кримінального законодавства, а також кодекс етичної поведінки. Однак ефективні санкції повинні застосовуватися не тільки до посадових осіб, які зловживають своїм становищем, а й до політиків. Однією з головних складових частин формування і реалізації ефективної системи боротьби з корупцією є чітка взаємодія держав, насамперед їхніх правоохоронних органів, на регіональному і міжнародному рівнях, участь у заходах боротьби із цим негативним явищем.

У статті досліджено проблеми протидіï корупціï в європейських країнах, проаналізовано позитивний досвід антикорупційної діяльності Німеччини, Франції, Румунї, Словаччини, особливості правової ретламентації кримінальної відповідальності за вчинення корупційних діянь у країнах Європи. Базовою складовою частиною успішної протидї корупиійним проявам $\epsilon$ належне антикорупційне законодавство. У вузькому розумінні антикорупиійне законодавство це закони й інші нормативно-правові акти, які встановлюють спеціальні законодавчі положення щодо запобігання корупиіï, визначають ознаки корупційних правопорушень та відповідальність за їх учинення, регулюють діяльність державних органів чи їхніх спеціальних підрозділів, до компетенції яких належить протидія корупціï, координація такої діяльності (контроль) та нагляд за нею. У процесі дослідження встановлено, що боротьба з корупцією досягає успіху лише за умови ї комплексного характеру, коли вона охоплюе якнайбільше сфер життєдіяльності держави, ведеться постійно та перебувае в центрі уваги як влади, так $i$ громадськості. Щоб отримати результат, необхідно, щзоби реформи були 
поєднані з іншими формами боротьби з корупцією - економічними, фінансовими, соціальними й організаційними. I, зрештою, велику роль у протидії корупції відіграе громадськість, особливо об'єднання громадян, які сприяють виявленню порушень законодавства про боротьбу з корупцією особами, уповноваженими на виконання функиій держави. Постійна поінформованість громадськості є ключовим елементом. Демократія та верховенство права є найкращим захистом від зловживання владою, оскільки вони накладають обмеження на владу держави та ї представників за допомогою обмежених у часі мандатів, верховенства права, а також посадових осіб, контроль за якими здійснюеться вільно обраними законодавчими органами, тобто за допомогою дієвого поділу влади, яким би чином він не здійснювався.

Ключові слова: антикорупційна політика, державні службовці, кримінальне законодавство, держави-члени $\in C$, запобігання і протидія корупції, кримінальна відповідальність.

Humeniuk T. Amenability of civil servants for corruption (on the example of select European countries)

The article examines the problems of combating corruption in European countries, analyzes the positive experience of anti-corruption activities in Germany, France, Romania, and Slovakia, the features of the legal regulation of criminal liability for corruption in European countries. A proper anti-corruption legislation is a basic component of successful anticorruption efforts. In a narrow sense, anti-corruption legislation includes laws and other regulations that establish special statutory provisions to prevent corruption, determine the characteristics of corruption offenses and responsibility for their commission, regulate the activities of state bodies or their special units responsible for combating corruption, coordination (control) of such activities, and supervision. The study has found that the fight against corruption succeeds only if it has comprehensive nature, covers as many areas of life in the state as possible on a regular bases, and remains the focus of both government and the public. In order to achieve results, it is essential to combine the reforms with other forms of anti-corruption, namely economic, financial, social, and organizational ones. Finally, the public plays an important role in combating corruption, especially associations of citizens, which contribute to the detection of violations of anticorruption legislation by persons authorized to perform state functions. Therefore, constant public awareness is a key element. Democracy and the rule of law are the best safeguards against abuse of power, as they impose restrictions on the power of the state and its representatives through timelimited mandates, the rule of law, and officials being controlled by freely elected legislative bodies, i.e. through effective separation of powers, no matter how it is carried out.

Key words: anti-corruptionpolicy, civilservants, criminal legislation, EU member states, preventing and combating corruption, criminal liability.

\section{Література}

1. Спеціалізовані інституції з боротьби проти корупції: огляд моделей. Організація економічного співробітництва i розвитку Мережа боротьби проти корупиії для країн Східної Европи $і$ Ценmральної Азї̈. URL: https: / / wrw.oecd.org / corruption/acn/39972270.pdf.

2. Янюк Н. Поняття «конфлікт інтересів» у міжнародно-правових актах та адміністративному законодавстві України. Вісник Львівського університету. Серія «Юридична». 2018. Bun. 66. C. 147-154. URL: http:// nbuv.gov.ua/UJRN/Vlnu_yu_2018_66_18. 
3. Губанов О. Види та нормативноправове регулювання юридичної відповідальності публічних службовиів у кpaїнаx EC. Visegrad journal on human rights. 2016. № 5. C. 25-29. URL: http:// vjhr.sk/archive/2016_5/part_1/9.pdf.

4. Буряк К. Особливості антикорупиійного законодавства в країнах Європейського Союзу. Підприємництво, господарство і право. 2020. Bun. 2. C. 356-360.

5. Бенедик B. Сутність та иляхи подолання конфлікту інтересів. Корупція в Україні: організаційно-правові аспекти протидіі / за заг. ред. В. Гаращука. Харків : ФОП Панов А.M., 2016. C. 92-111.

6. Підбережник $H$. Антикорупційна політика в країнах західної Європи: досвід для України. Ефективність державного управління. 2013. Bun. 37. C. 123-132. URL: http:// nbuv.gov.ua/UJRN/efdu_ 2013_37_18.
7. Управлінські механізми запобігання та протидії корупції в європейських державах: досвід для України : наукова розробка / авт. кол. : О. Красівський та ін. ; за заг. ред. О. Красівського. Київ : НАДУ, 2014. 52 с.

8. Ахтирська Н. Міжнародний досвід боротьби з корупиією як вектор формування національної антикорупційної політики: огляд законодавства Румунії. Biчe. 2015. № 18. C. 2-5. URL: http:// nbuv.gov.ua/UJRN/viche_2015_18_2.

9. Внутрішній звіт про антикорупційні заходи в Європі: сфери діяльності, досвід, інструменти. 2-е засідання, Брюссель, 11 лютого 2016 р. Проект підготовлений Крістіаном Моосом, иленом EECK. URL: http: / / wrw.eesc.europa.eu/ sites / default / files / resources / docs / reportcorruption_ukr.pdf. 